\title{
Representation of knowledge in digital educational environments: A systematic review of literature
}

\author{
Mauricio Buitrago \\ Universidad Libre \\ Andrés Chiappe
Universidad de La Sabana
}

The representation of knowledge is a process widely used in education for its potential to generate deep learning, metacognition, and also in mapping the student's cognitive structure while developing a broad spectrum of thinking skills. Notwithstanding the abovementioned benefits, the development and evolution of new digital ecologies of learning is still an unexplored field for knowledge representation systems. As part of a larger study, this article shows the process and results of a systematic review of literature on knowledge representation systems, with the purpose of identifying the foundations and main applicable instruments of digital educational environments. Among the most representative findings of this review is that despite the existence of a large number of educational experiences that have incorporated both physical and digital knowledge representation tools, their use has been restricted almost entirely to the understanding of concepts and the assessment of learning in non-collaborative environments. These findings suggest the relevance of studying the representation of knowledge in digital collaborative contexts that facilitate the development of thinking skills for the digital age, and the need for co-creation and transformation of knowledge. Together these suggest a new perspective on knowledge representation for digital ecologies of learning.

\section{Introduction}

Knowledge can be understood as "a network of strongly connected cognitive elements representing generic concepts in memory" (Juuti, Lehtonen, \& Rättyä, 2012, p. 4). These concepts in turn are understood as the set of objects, events, and ideas, which are used to define and explain the human experience and constitute the basic unit of knowledge. This idea is highlighted in several studies on the representation of knowledge in which concepts are understood as regularities that serve to explain what is known (Gog, Kester, Nievelstein, Giesbers, \& Paas, 2009). Names or labels are used for their designation. These regularities are then constructed under the influence of science and use primarily human language as a means of transmission and production.

In this way, and considering that human language has diversified due to the influence of information and communication technologies (ICT) and the new forms and means of digital communication, it becomes necessary that society today is asking for new strategies to build and manage knowledge (Correia, 2012). This management presupposes access and use of activities linked to the generation and transmission of knowledge in these new digital environments. Thus, the school as a space for transmission and generation of knowledge is called upon to enter the debate on how mechanisms, processes, and instruments are best combined to ensure the representation of knowledge.

The representation of knowledge is a phenomenon that has been studied for a long time in the areas of cognitive psychology, education, and knowledge engineering, and more recently in areas of intelligent systems and artificial intelligence. Balke and Mainzer (2005) state:

The representation of knowledge has a long tradition in logic and philosophy. Automated reasoning with ontologies and categories has been discussed in philosophy, before being formalized in artificial intelligence and applied in information systems. However, most of our knowledge is implicit and unconscious, situated and personalized. It is not formally represented, but incorporated knowledge, which is learned by doing, is applied by selforganization and is understood by bodily interaction with social environments. (p.586) 
In opposition to the implicit and unconscious knowledge approach formerly described, the representation discussed in this article refers to the formal representation of explicit knowledge, that is, all that which relies on human language and the instruments created by humankind to transmit it, to produce it and to visualise it through instruments and processes of institutionalised learning that usually happen at school. These learning processes are given, as explained by Rodriguez (2012) and Richland and Hansen (2013) in four ways: learning by memory, learning by deduction, learning by induction, and learning by analogy. Thus, the process of knowledge acquisition seems to be strongly related to how people use knowledge representation instruments (KRIs) that serve to memorise, deduce, induce, and establish analogies. This approach seeks to recognise that human knowledge is not limited to those things we learn in school, but instead, it takes place across areas and stages of human experience and development. It is well known that "human experts not only rely on rule-based explicit (declarative) representations, but also on intuition and implicit (procedural) knowledge" (Balke \& Mainzer, 2005, p. 588).

Therefore, the representation of knowledge as set forth by Whimbey, Lochhead, and Narode (2013), is related to making evident the ways in which we acquire, store, and process information. This is called thinking aloud. In this way, representing knowledge implies the deployment of a set of thinking skills that make it possible to visualise that way of thinking, which is concretised through graphic instruments to represent a conceptual relationship which is called conceptual mapping (O’Donnell, Dansereau, \& Hall, 2002).

This idea is confirmed by Hay, Kinchin, and Lygo-Baker (2008), who pose that conceptual mapping makes learning visible to the extent that students can make explicit some conceptual mastery. In this perspective, studies such as Gog et al. (2009), explain conceptual mapping, especially in the context of higher education, in which knowledge is expected to be produced rather than transmitted. This process activates regions of the brain associated with how we encode both lexical and syntactic information (Fedorenko, NietoCastanon, \& Kanwisher, 2012; Goldberg, Perfetti, \& Schneider, 2006), and allows for dynamic thinking: "the participation of teachers and students in the processes of discovery" and generation of knowledge (Hay et al., 2008, p. 309).

Hence, the visualisation of knowledge obtained with the use of the KRIs, makes possible "the development of the holistic understanding that words alone can't convey, because the graphic form allows for representations of parts and all, in a way that is not available in the sequential structure of the text" (Adodo, 2013 , p. 163). It is worth noting that research on knowledge representation in the educational context is often framed in what some researchers call conceptual mapping. Under this name, KRIs such as knowledge maps, concept maps, mental maps, and Gowin's V diagram are included. Concept mapping then uses tools and techniques that are used to assess the content and quality of cognitive structures (schemes) before and after an instructional intervention (Gog et al., 2009). In this way, conceptual cartography is a powerful tool in the teaching and learning processes, since "it can be used to transform abstract knowledge and understanding into concrete visual representations that can be compared and measured" (Hay et al., 2008, p. 295).

It is noteworthy that while, the representation of knowledge and its instruments are widely discussed in the literature, an initial exploration associating that subject with digital learning environments, such as elearning, MOOC, social network usage, or personal learning environments (PLE) (Figure 1), shows the existence of a research gap, which should become a very interesting space in which to undertake educational research processes. 


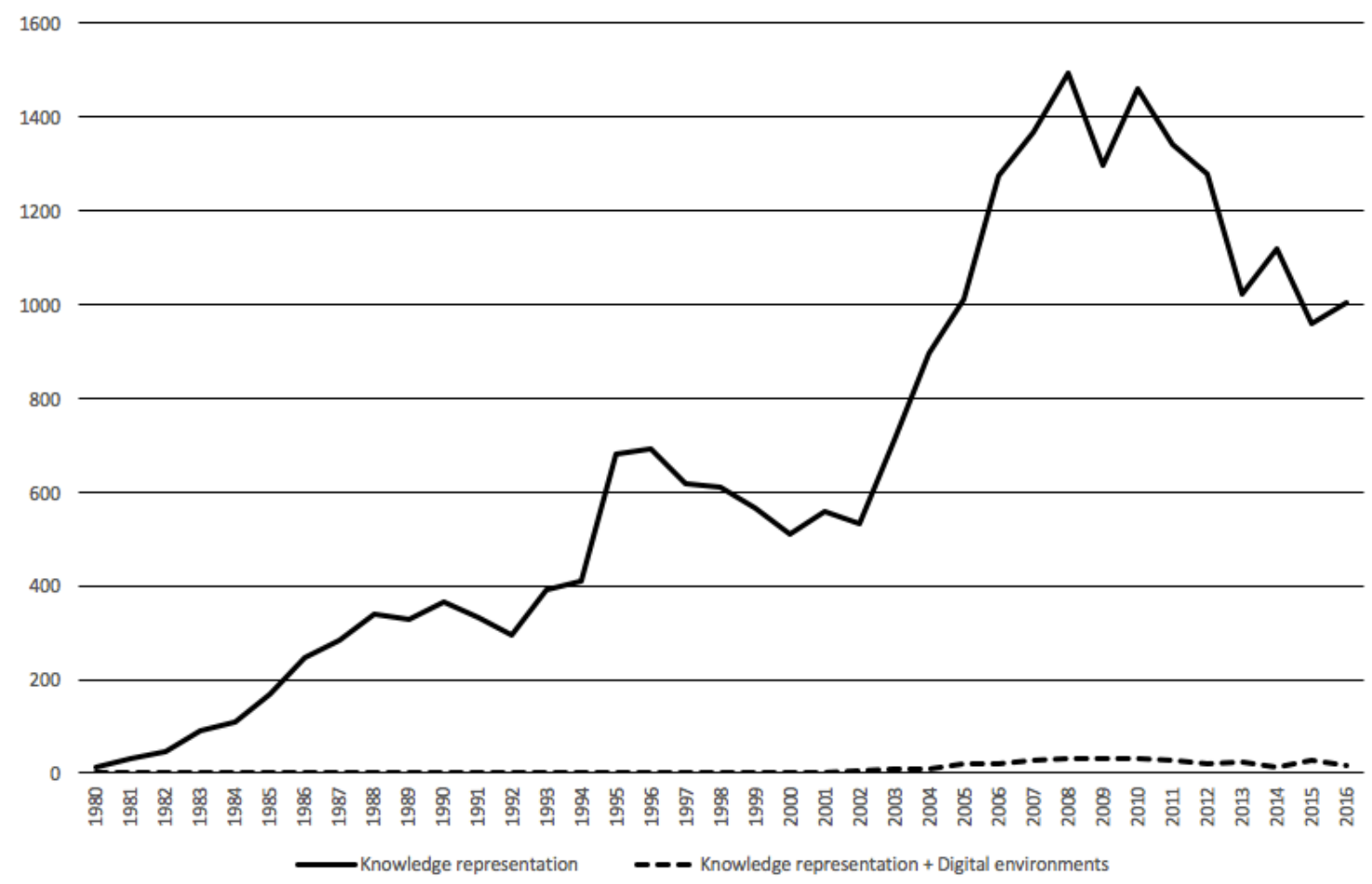

Figure 1. Knowledge representation + digital environments in Scopus

The representation of knowledge is key in the current processes of teaching and learning because it favours the formation of thinking skills and promotes educational practices based on deep and meaningful learning. Because information and communication technologies determine in part the development of the resources that are used today for the development of KRIs in education, it is pertinent to carry out a literature review on the use of such instruments in the educational field in order to explore their potential use in digital environments. This is especially related to the development of thinking skills appropriate to twenty-first century educational scenarios.

\section{Method}

The review process was designed taking into account the phases recommended by Ke (2009), from which a review protocol was developed that covered the following processes: determining the review's purpose, defining inclusion/exclusion criteria, initial searching, abstracting, reading in depth, data analysis, interpretation, and discussion of results. The synthesis of the process is shown in Figure 2.

\section{Determining review's purpose}

A first key process of a literature review has to do with establishing an approach that allows it to be effectively and orderly addressed, mainly through the formulation of guiding questions (Hall, Beecham, Bowes, Gray, \& Counsell, 2012). For this purpose, four guiding questions were drawn up:

1. What are the instruments of knowledge representation mostly used in education?

2. What are the educational activities and processes in which the instruments of knowledge representation are used?

3. Which learning theories guide the use and conception of the instruments of representation of knowledge in those activities and processes?

4. What thinking skills are promoted or developed through the instruments of knowledge representation? 


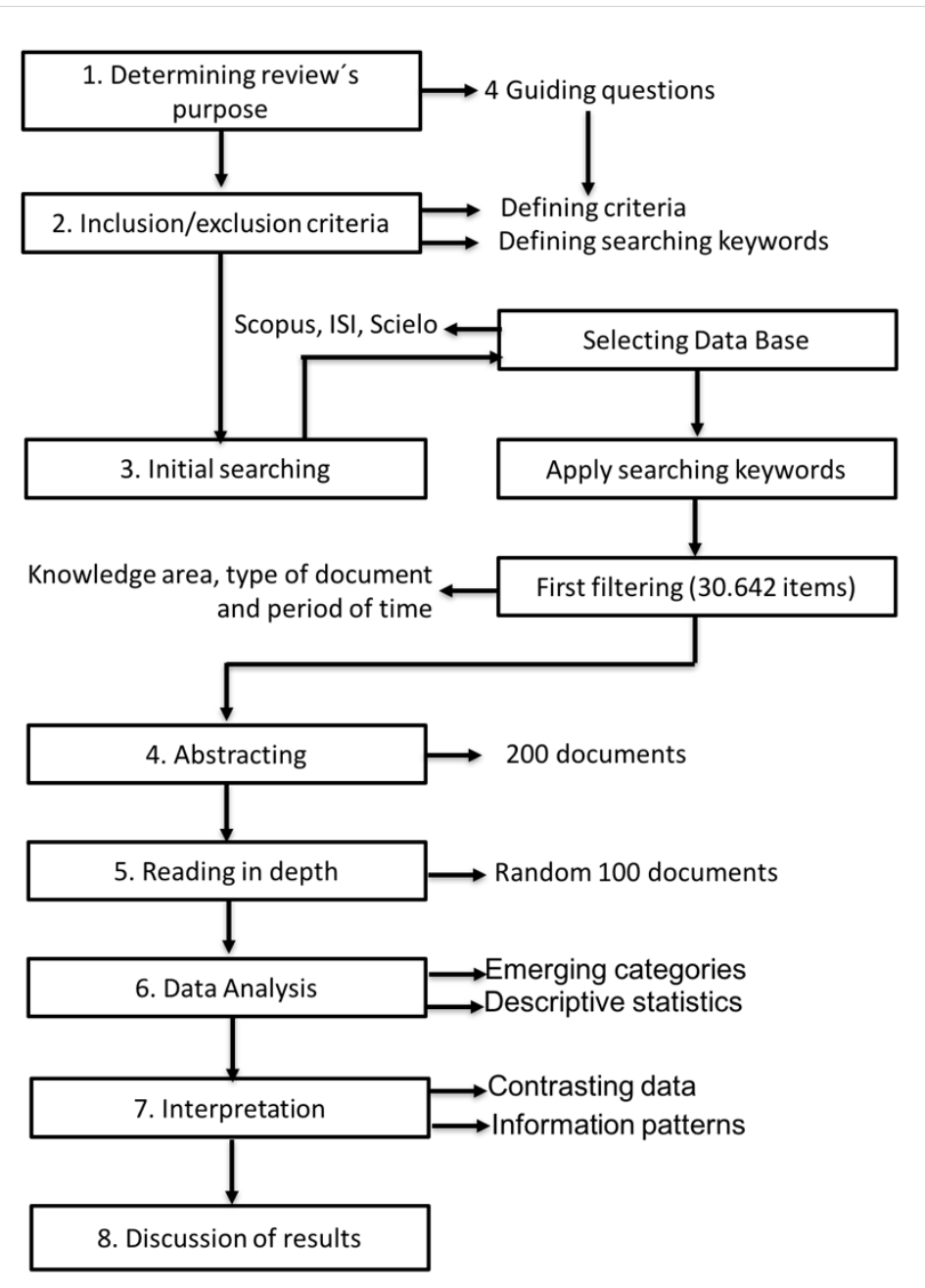

Figure 2. Review method

\section{Defining inclusion/exclusion criteria}

In the second phase of the literature review, inclusion and exclusion criteria were determined as described in Table 1.

Table 1

Inclusion and exclusion criteria - pre-selection of documents.

Inclusion criteria

Knowledge representation must be the central topic.

They must be documents of the type research article or review article.

Valid documents must respond to the keywords "knowledge representation", "knowledge modeling", or "knowledge mapping" both in Spanish and English.

Valid documents must be related to the educational use of knowledge representation.

Valid documents must involve the use of knowledge representation instruments.

Searching must consider documents published between 1980 and 2017.

Valid documents should provide relevant information to answer some of the guiding questions.

Exclusion criteria

Notes, editorials, books, and book chapters are excluded.

Representation of knowledge in non-human systems are excluded. 


\section{Initial searching}

This phase was divided into three processes, the first of which consisted in the selection of the searching databases. Taking into account the multidisciplinary nature of the review topic, it was considered pertinent to select three major data bases that covered research papers in peer-reviewed high impact factor journals in Spanish and English: ISI Web of knowledge, Scopus and Scielo. The second process was the application of searching keywords as follows: "knowledge representation", "knowledge modeling", or "knowledge mapping" both in Spanish and English. Finally, a filtering process was applied by knowledge area, type of documents and period of time. This initial searching returned 30,642 results.

\section{Abstracting}

From total results, an abstracts analysis was carried out and, based on the application of the inclusion criteria, 200 documents were preselected. To determine the amount of documents to be read in depth later, it was proposed as appropriate to take twice the average of the production of texts in each selected period of time, which yielded $50 \%(n=100)$ of the preselected documents. The number of documents that were to be read in depth for each database in the 4 decades covered by the review (1980 to 2017) was determined by means of a percentage distribution analysis. (Table 2)

Table 2

Preselection of documents for further reading in depth

\begin{tabular}{crrrrr}
\hline Documents by database & $1980-1990$ & $1991-2000$ & $2001-2010$ & $2011-2017$ & Total \\
\hline Documents in Scopus: & 830 & 3,056 & 11,298 & 11,922 & 27,106 \\
Number selected & 3 & 10 & 37 & 39 & 89 \\
Percentage selected & $2.71 \%$ & $9.97 \%$ & $36.87 \%$ & $38.91 \%$ & $88.46 \%$ \\
Documents in ISI: & 0 & 0 & 1,909 & 1,284 & 3,193 \\
Number selected & 0 & 0 & 6 & 4 & 10 \\
Percentage selected & $0 \%$ & $0 \%$ & $6.23 \%$ & $4.19 \%$ & $10.42 \%$ \\
Documents in Scielo: & 0 & 6 & 144 & 193 & 343 \\
$\quad$ Number selected & 0 & 0 & 1 & 1 & 2 \\
$\quad$ Percentage selected & $0 \%$ & $0.02 \%$ & $0.47 \%$ & $1.0 \%$ & $1.49 \%$ \\
Total & 830 & 3,062 & 13,351 & 13,399 & 30,642 \\
Percentage & $2.71 \%$ & $9.99 \%$ & $43.57 \%$ & $43.73 \%$ & $100 \%$ \\
\hline Preselected documents: & 5 & 20 & 87 & 88 & 200 \\
$\quad$ Scopus & 5 & 20 & 74 & 80 & 179 \\
$\quad$ ISI & 0 & 0 & 12 & 8 & 20 \\
$\quad$ Scielo & 0 & 0 & 0 & 1 & 1 \\
\hline Documents for in-depth reading & 2 & 10 & 44 & 44 & 100 \\
\hline
\end{tabular}

\section{Reading in depth}

The 100 documents selected were finally read in depth. Key ideas related to one of the four guiding questions were extracted. These key ideas were entered into a shared database so that at least two members of the research team had access to the data so that they could then do an inter-rater validation. The key ideas encountered underwent a process of homologation, unification, and grouping, which later allowed the construction of emerging categories of analysis. The validation of these categories was performed using the Cohen's Kappa coefficient, which obtained a result of $K=0.64$, which corresponds to an acceptable interrater valuation of reliability (Vieira, Kaymak, \& Sousa, 2010). An additional element of information reliability was measured from the quality of its sources. Table 3 shows the detail of the top 10 journals that showed the highest frequencies of occurrence of key ideas associated with the representation of knowledge. 
Table 3

Top 10 journal-article frequency

\begin{tabular}{lccc}
\hline Journal & Frequency & SJR Quartile & Impact Factor \\
\hline Knowledge-Based Systems & 9 & Q1 & 1.88 \\
Computers \& Education & 6 & Q1 & 2.61 \\
Educational Technology \& Society & 5 & Q1 & 1.1 \\
Journal of Research in Science Teaching & 5 & Q1 & 2.87 \\
Artificial Intelligence & 4 & Q1 & 2.04 \\
Computers in Human Behavior & 4 & Q1 & 1.6 \\
Expert Systems with Applications & 4 & Q1 & 1.43 \\
Educational Psychology Review & 3 & Q1 & 1.64 \\
Educational Technology Research and Development & 3 & Q1 & 1.31 \\
Higher Education & 3 & Q1 & 1.49 \\
\hline
\end{tabular}

It should be mentioned that the average number of journals per journal is low (1.24), so it means that there is a fairly homogeneous distribution of publications that have addressed the representation of knowledge from the perspective of educational research.

\section{Data analysis}

The categories of analysis that were used for the literature review corresponded to the four guiding questions. From the above, and based on identified key ideas, the emergent categories were formulated as shown below:

1. What are the KRIs mostly used in education?

Categories: conceptual maps, knowledge maps, mindmapping, Gowin's V diagrams, cross-modal maps, argumentative maps, tree diagrams.

2. What are the educational activities and processes in which KRIs are used?

Categories: concept representation, decision making, learning to learn, problem solving, organise information/ideas, promoting learning, developing information systems, assessment of learning, improve reading, comprehension, analyse cognitive styles.

3. What learning theories guide the use KRIs?

Categories: constructivism, behaviorism, connectivism, other learning theory.

4. What thinking skills are promoted or developed through KRIs?

Categories: remember, understand, apply, analyse, evaluate, create.

\section{Interpretation}

In order to analyse the results, a simple statistical analysis was conducted in which processes of frequency analysis and co-occurrences were carried out, and the most prominent concepts were identified within the global set of results. The interpretation of the results was generated in accordance with the guiding question and the emerging categories mentioned previously. A more qualitative process was undertaken based on the comparison of text segments extracted from the selected articles. In those segments we sought repeated ideas and issues associated with such ideas or patterns of information that might be relevant to the purpose of the review.

\section{Discussion of results}

This last process had to do with the identification of the implications and relevance of the results in relation to the area of knowledge within which the object of study of this review is located. In addition, possible spaces for future research in this area were addressed and the limitations of this revision were established as an educational research process.

\section{Results}

The data analysis raised a total of 324 key ideas related to the representation of knowledge, with 720 instances of frequency. Table 4 shows the top 30 key ideas, their frequency, and percentage of representativeness within the total found data. 
Table 4

Frequency of top 30 key ideas

\begin{tabular}{lrrlrc}
\hline Key idea & \multicolumn{1}{c}{ 其 } & \multicolumn{1}{c}{$\%$} & Key idea & $\#$ & $\%$ \\
\hline Concept mapping & 109 & $15.14 \%$ & Social networks & 8 & $1.11 \%$ \\
Knowledge management & 22 & $3.06 \%$ & Knowledge structures & 7 & $0.97 \%$ \\
Cognitive process & 21 & $2.92 \%$ & Semantic web & 7 & $0.97 \%$ \\
Cognitive mapping & 19 & $2.64 \%$ & Techniques & 7 & $0.97 \%$ \\
Knowledge mapping & 19 & $2.64 \%$ & Learning & 6 & $0.83 \%$ \\
Semantic representation & 18 & $2.50 \%$ & Problem solving & 5 & $0.69 \%$ \\
Graphical representation & 17 & $2.36 \%$ & Tool & 5 & $0.69 \%$ \\
Mind mapping & 17 & $2.36 \%$ & Artificial intelligence & 4 & $0.56 \%$ \\
Ontologies & 11 & $1.53 \%$ & Brain functions & 4 & $0.56 \%$ \\
Information visualisation & 9 & $1.25 \%$ & Critical thinking & 4 & $0.56 \%$ \\
Cognitive style & 8 & $1.11 \%$ & Knowledge construction & 4 & $0.56 \%$ \\
Decision making & 8 & $1.11 \%$ & Knowledge engineering & 4 & $0.56 \%$ \\
Knowledge acquisition & 8 & $1.11 \%$ & Topic map & 4 & $0.56 \%$ \\
Mapping & 8 & $1.11 \%$ & Visualisation & 4 & $0.56 \%$ \\
Reasoning & 8 & $1.11 \%$ & Causality & 4 & $0.56 \%$ \\
\hline
\end{tabular}

A first issue to highlight among the results is related to educational contexts in which KRIs have been applied. In this sense, research on the use of KRIs in education indicates that these instruments have been used extensively in all educational levels ranging from primary basic education (McLay \& Brown, 2003), to secondary education (Ciullo, Falcomata, Pfannenstiel, \& Billingsley, 2015; Defranco, Jablokow, Bilen, \& Gordon, 2012; Guimarães, Chambel, \& Bidarra, 2000; Jacobs-Lawson \& Hershey, 2002), and to higher education (Adodo, 2013; Chang, Sung, \& Chen, 2002; Davies, 2011; Defranco, Jablokow, Piovoso, \& Richmond, 2015; Tseng, Chang, Lou, Tan, \& Chiu, 2012). Many studies describe the use of KRIs in contexts that go beyond formal education. Some of these studies, for example, have to do with decision making in aspects such as integrated water management (Kolkman, Kok, \& van der Veen, 2005) or knowledge management processes (Gordon, 2000). There are even several examples of using KRIs in the business context (Driessen, Huijsen, \& Grootveld, 2007), where they are usually used in decision-making educational processes in organisations such as marketing (Jahan \& Hamilton, 2017). In all these cases, knowledge is understood as a value of modern organisations, where it is usually classified as the most important asset. Finally, it is important to mention the notable absence of studies on knowledge representation within highly informatised, digital, flexible, and networked educational contexts such as MOOCs, in which there are vast opportunities to apply learning analytics as an integral part of the representation systems of knowledge.

\section{Most used knowledge representation instruments}

Figure 3 shows the percentages of use of KRIs that are most applied in education. These instruments refer to conceptual maps, Gowin's V diagrams, mind maps, knowledge maps, tree diagrams, and other types of schemes used in the visual representation of concepts, ideas, processes, and events. 


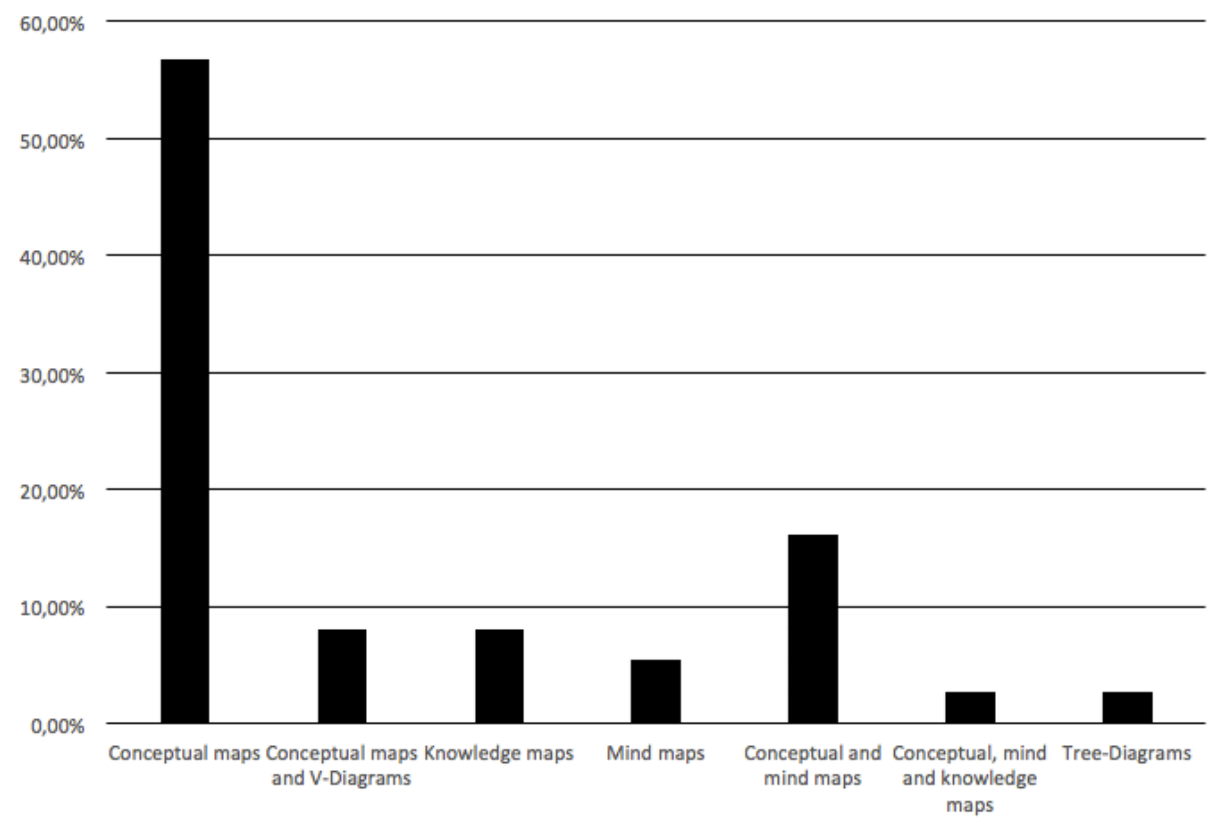

Figure 3. Most used KRIs in education

The results indicate that there is a variety of knowledge representation tools ranging from concept maps to tree-diagrams, usually applied in decision making processes. Conceptual maps however, remain the most well-known, studied and used KRIs in the context of educational research. As shown in Figure 3, there are studies where only conceptual maps are reported, as well as studies reporting the use of these in conjunction with other KRIs, so there is a total of $83.78 \%$ of occurrence frequency in research reflecting the use of concept maps as KRIs in the context of educational research.

On the other hand, mind maps (16.22\%) double the use of knowledge maps and Gowin's V diagrams (each with $8.11 \%$ ). The least used KRIs are tree-diagrams $(2.70 \%)$ and other KRIs that do not receive a specific denomination but are treated only as graphics (Seufert, 2003). It is noteworthy that several of the studies considered refer to both the concept maps and the mind maps, defining them as tools of interesting visual representation used to show a conceptual relation, hence, in several studies, the differences between the two are not exactly detailed, and they are referred to indistinctly as knowledge maps (Fionda, Gutierrez, \& Pirrò, 2016; Guimarães et al., 2000). This suggests one more reason to think about conceptual maps as the most widespread used KRIs in the processes of knowledge representation. Adodo (2013) states:

Mind-mapping is a method that can be used to visualize the structure of knowledge, expressed in the maps is mostly semantic; concept maps are sometimes called semantic networks. Often it is claimed that concept mapping bears a similarity to the structure of longterm memory. Visual symbols are quickly and easily recognized and this can be demonstrated by considering the large amount of logos, maps, arrows, road signs and icons that most of us can recall with little effort. (p. 163)

\section{Educational activities and processes using KRIs}

Results showed that there are at least 10 different types of educational activities in which KRIs are used consistently. The results from a descriptive statistical analysis can be seen in Figure 4. 


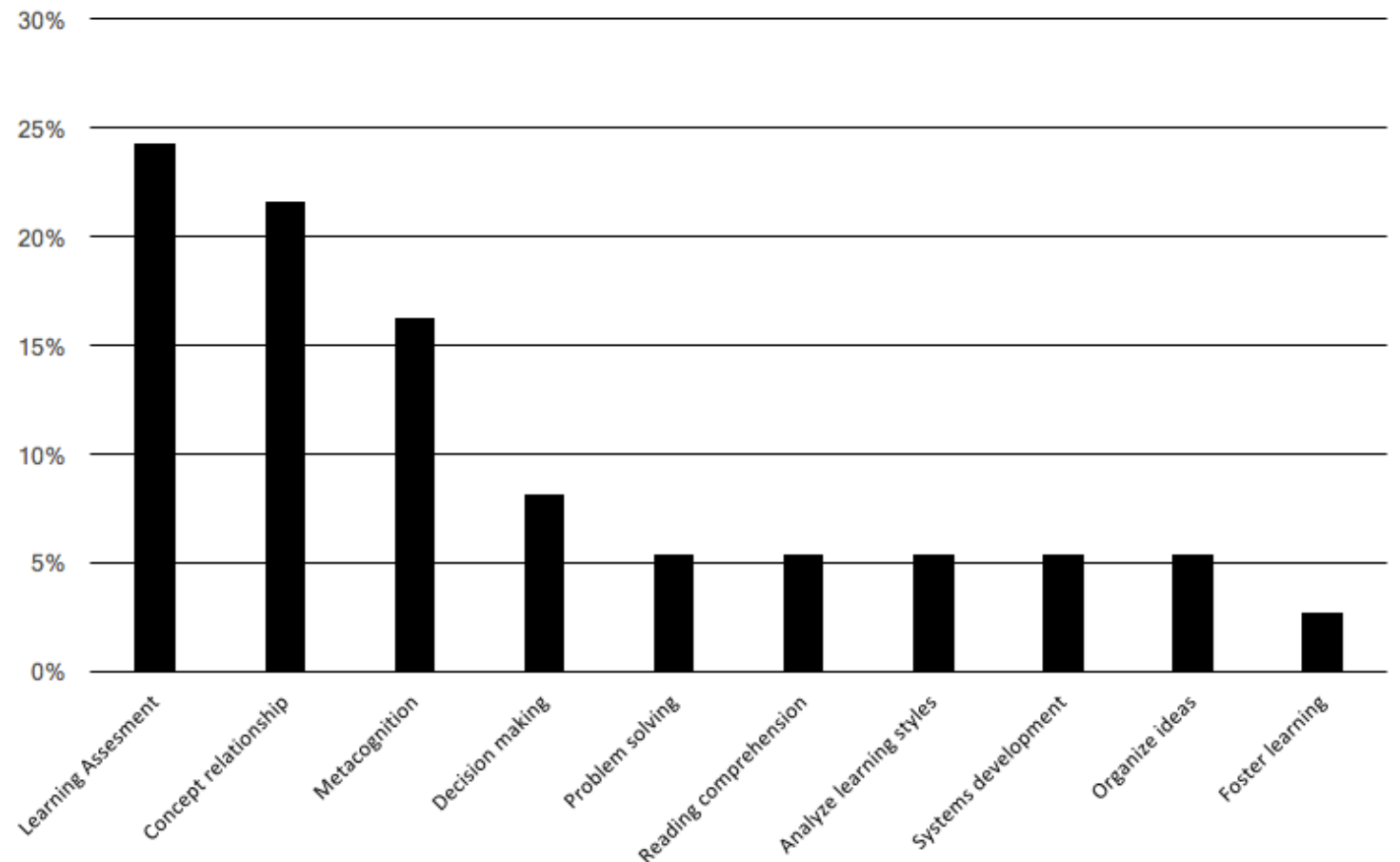

Figure 4. Use of KRIs

By doing an exercise of categorisation of the activities in which KRIs are used, four types of educational processes could be considered: (1) teaching, (2) organisation of information, (3) assessment, and (4) management. Table 5 establishes a relationship between educational processes and activities in which KRIs are used.

Table 5

Educational processes and activities using KRIs

\begin{tabular}{llrr}
\hline Educational process & Educational activities & Activity \% & Process \% \\
\hline \multirow{3}{*}{ Teaching } & Organise ideas & $5.41 \%$ & \\
& Foster learning & $2.70 \%$ & $13.52 \%$ \\
& Improve reading comprehension & $5.41 \%$ & \\
\hline Organisation of information & Concept representation & $21.62 \%$ & $21.62 \%$ \\
\hline \multirow{3}{*}{ Assessment } & Metacognition & $16.22 \%$ & \\
& Assessment of learning & $24.32 \%$ & 4 \\
& Analyse learning styles & $5.41 \%$ & \\
\multirow{3}{*}{ Management } & Decision making & $8.11 \%$ & \\
& Problem solving & $5.41 \%$ & \multirow{2}{*}{$18.93 \%$} \\
& System development & $5.41 \%$ & \\
\hline
\end{tabular}

It is interesting to mention that although from the perspective of educational processes, the greatest use of KRIs is reported concerning evaluation, whether focused on assessment of learning (Jacobs-Lawson \& Hershey, 2002) or on the determination of students' cognitive styles (Correia, 2012; Jablokow, Defranco, Richmond, Piovoso, \& Bilén, 2015), from a concrete activity approach, its use focuses mainly on the representation of concepts, which is consistent with the considerations of Novak and Cañas (2006).

\section{Pedagogical foundation of KRI's use on educational processes}

While behaviourism and constructivism are pointed out as learning theories that give psycho-cognitive support to the use of KRIs in education, it is striking that more than $50 \%$ of studies do not report relying on any particular learning theory. Among those who report this data (approximately 1 in 20), 40.54\% affirm that they rely on constructivist learning theory. From a pedagogical perspective, it is interesting to mention 
that since connectivism or networked learning are part of the most relevant growing educational trends in the twenty-first century context, its presence as a pedagogical foundation associated with the use of KRIs is practically null.

\section{Knowledge representation and thinking skills}

The analysis of data for this category was based on the revised version of Bloom's taxonomy for the digital age (Churches, 2008; Krathwohl, 2002; Skiba, 2013). As it is shown in Figure 5, this revised taxonomy establishes six thinking skills (remember, understand, apply, analyse, evaluate and create), arranged in a way that alludes to three processes: acquisition, deepening, and creation of knowledge. These skills can also be analysed at 2 levels: those that refer to low order thinking skills (LOTS) and those that refer to high order thinking skills (HOTS).

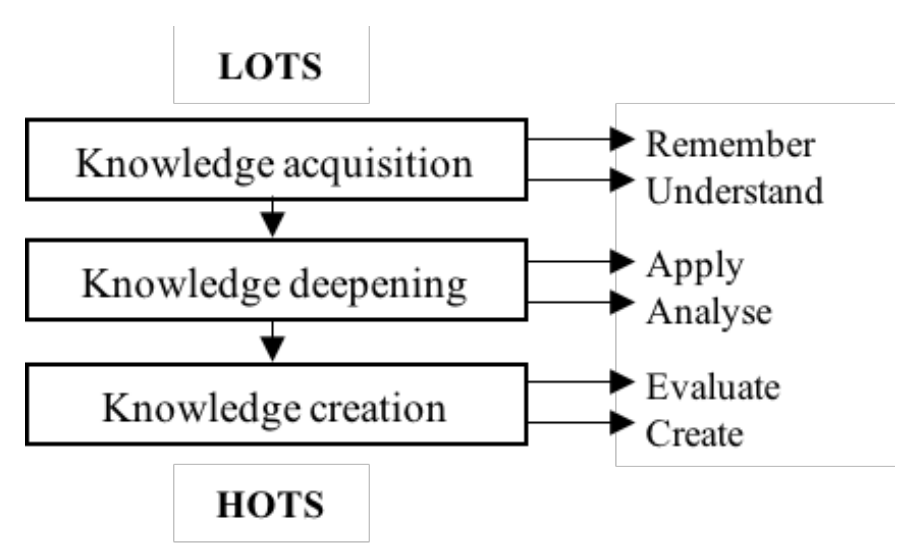

Figure 5. Bloom's taxonomy for the digital age

As can be seen in Table 6, the most prevalent thinking skill to develop through the use of KRIs is understand (48.65\%), followed by evaluate (24.32), apply (13.51\%), remember $(10.81 \%)$, and create $(2.70 \%)$, with analyse last $(0 \%)$. This is consistent with the data shown in Table 5 where the educational activity "assessment of learning", and the "assessment process" are the elements with the highest value.

Table 6

Thinking skills developed using KRIs

\begin{tabular}{lr}
\hline Thinking skills & $(\%)$ \\
\hline Remember & $10.81 \%$ \\
Understand & $48.65 \%$ \\
Apply & $13.51 \%$ \\
Analyse & $0.00 \%$ \\
Evaluate & $24.32 \%$ \\
Create & $2.70 \%$ \\
\hline
\end{tabular}

These results show that the use of KRIs in education is significantly inclined towards the development of low level thinking skills, remember and understand, which together total 59\%, indicating an instrumental use of KRIs. On the other hand, it is also observed a significant use of KRIs as resources to support assessment and not as resources to support meta-evaluation processes, which again indicates the instrumental use of these means.

\section{Discussion and concluding remarks}

From the results shown in Tables 5 and 6, and in Figure 5, it can be affirmed that the uses of the KRIs are currently oriented to:

i. Teaching processes based on activities such as organising information and representing concepts, which point to the development of thinking skills of remember and understand, which are part of the knowledge acquisition process. 
ii. Processes of organisation of information from activities such as representing concepts, which are oriented to the development of the skills of remember and understand, which are part of the process of knowledge acquisition.

iii. Evaluation processes from activities such as learning to learn and evaluate learning, which are oriented to the development of the skill of evaluate, which is part of the process of knowledge creation.

iv. Process management processes based on activities such as making decisions and solving problems, which are oriented to the development of apply and create skills, which are part of the process of deepening and creating knowledge.

The abovementioned statements are also explained in Table 7.

Table 7

Educational processes, educational activities, knowledge processes, and thinking skills using KRIs

\begin{tabular}{|c|c|c|c|c|c|}
\hline $\begin{array}{l}\text { Educational } \\
\text { process (EP) }\end{array}$ & Educational activities & $\begin{array}{c}\text { Activity } \\
\%\end{array}$ & $\mathrm{EP} \%$ & $\begin{array}{l}\text { Knowledge } \\
\text { process (KP) }\end{array}$ & $\begin{array}{l}\text { Thinking } \\
\text { Skills (TS) } \\
\%\end{array}$ \\
\hline Teaching & $\begin{array}{l}\text { organise ideas } \\
\text { foster learning } \\
\text { improve reading comprehension }\end{array}$ & $\begin{array}{l}5.41 \% \\
2.70 \% \\
5.41 \% \\
\end{array}$ & $13.52 \%$ & \multirow[t]{2}{*}{$\begin{array}{l}\text { knowledge } \\
\text { acquisition }\end{array}$} & \multirow{2}{*}{$\begin{array}{c}59.46 \% \\
\text { (remember } \\
\text { and } \\
\text { understand) }\end{array}$} \\
\hline $\begin{array}{l}\text { Organisation of } \\
\text { information }\end{array}$ & concept representation & $21.62 \%$ & $21.62 \%$ & & \\
\hline Assessment & $\begin{array}{l}\text { metacognition } \\
\text { assessment of learning } \\
\text { analyse learning styles }\end{array}$ & $\begin{array}{r}16.22 \% \\
24.32 \% \\
5.41 \% \\
\end{array}$ & $45.95 \%$ & $\begin{array}{l}\text { knowledge } \\
\text { creation }\end{array}$ & $\begin{array}{c}27.02 \% \\
\text { (evaluate } \\
\text { and create) } \\
\end{array}$ \\
\hline Management & $\begin{array}{l}\text { decision making } \\
\text { problem solving } \\
\text { system development }\end{array}$ & $\begin{array}{l}8.11 \% \\
5.41 \% \\
5.41 \%\end{array}$ & $18.93 \%$ & $\begin{array}{l}\text { knowledge } \\
\text { deepening }\end{array}$ & $\begin{array}{c}13.51 \% \\
\text { (apply and } \\
\text { analyse) }\end{array}$ \\
\hline
\end{tabular}

The results confirm the notion that KRIs are used in the educational field, mainly to support instructional processes through knowledge acquisition processes based on the use of tools such as conceptual maps (Ciullo et al., 2015, Dexter \& Hughes, 2011, Novak, Gowin, \& Johansen, 1983; Novak, 1998; O'Donnell et al., 2015; Rudell \& Boile, 1989). However, if it is accepted that knowledge acquisition processes differ from knowledge creation and evaluation processes, there is a lack of studies in which these are investigated simultaneously for the development of LOTS and HOTS when KRIs are used. On the other hand, the results reflect a less widespread use of KRIs in knowledge deepening processes that have relation with problem solving, decision making, and system development, pinpointing that the less used KRIs are tree diagrams and Gowin's V diagrams. These results could reflect the orientation of both, previous and current educational practices, towards knowledge transfer processes where conceptual maps effectively constitute a powerful tool. Likewise, they could indicate the need to work with KRI in the educational field, focusing on knowledge transfer and application processes (one of the current problems of twenty-first century education). This suggests that KRIs should be used as resources for the development of deep learning practices that surpass the school's vision as a place in which knowledge is transmitted through a teachercentred approach, and place it in turn, as a resource that supports student learning development. This argument is completely aligned with the ideas of Valenzuela (2008) that affirm that deep learning is achieved when the student has the ability to express the relationships between the concepts and general and particular subjects of a discipline, as well as with others from other disciplines and those that affect the student's daily life.

In today's educational settings, students now have access to a wide range of opportunities and resources mediated by technology. However, these opportunities are not always contextualised and handled appropriately (either by the instructional agents or by the students themselves), resulting in poor design and/or implementation of the instructional process. Within these resources, KRIs continue to be instruments focused on a traditional vision of knowledge and continue to see students as consumers of content, the school as a social institution to transmit them and, therefore, the use that is given to KRIs privileges the transmission and not the creation of knowledge. Besides, the knowledge society defined by Drucker (2011) 
is strongly constructed from a knowledge perspective in the digital age. This condition requires not only to rethink what should guide the search for new knowledge, but also the way in which society in general, and the school, in particular, can design a system to reproduce and represent them in a way that allows capturing the complexity and dynamism of the changes that are taking place.

We argue that a convenient way to examine the challenges of knowledge representation today is to propose an analysis of the four questions that guide the development of this study, which were described in the section "Determining review's purpose". On the one hand, the analysis collects the findings that describe the studies on the use of KRIs, and on the other, it raises the possibilities of their future use, specifically in a context dominated by digital ecologies, as shown in Table 8 .

Table 8

Findings and possibilities of the KRIs: A proposed analysis from the purposes of the research

\begin{tabular}{|c|c|c|}
\hline $\begin{array}{c}\text { Categories of } \\
\text { analysis }\end{array}$ & Findings & Future possibilities \\
\hline $\begin{array}{l}\text { What are the } \\
\text { instruments of } \\
\text { knowledge } \\
\text { representation } \\
\text { mostly used in } \\
\text { education? }\end{array}$ & $\begin{array}{l}\text { The KRIs mentioned in the studies } \\
\text { indicate the use of concept maps, mind } \\
\text { maps, Venn diagrams, tree diagrams, } \\
\text { etc. In general, these are KRIs that are } \\
\text { used as graphic visualisation tools } \\
\text { (usually in 2D) of the concepts and the } \\
\text { relationship between concepts. These } \\
\text { relationships, in most of the studies that } \\
\text { were reviewed, are given a linguistic } \\
\text { use, as they act as abstract mental } \\
\text { representations that a speaker makes } \\
\text { and that allow him/her to make use of } \\
\text { language in both formal and informal } \\
\text { contexts. } \\
\text { Although it has not been mentioned in } \\
\text { the studies reviewed, the reported use } \\
\text { of KRIs, as indicated above, suggests } \\
\text { an understanding of the concept of } \\
\text { knowledge, in which it is understood as } \\
\text { the set of concepts of a discipline that } \\
\text { can be represented as regularities (Gog } \\
\text { et al., 2009). Under this perspective, } \\
\text { these regularities are then constructed } \\
\text { under the influence of science and use } \\
\text { mainly human language and school as } \\
\text { a means of transmission and } \\
\text { production. }\end{array}$ & $\begin{array}{l}\text { If it is accepted that knowledge in the } \\
\text { digital age is created anywhere at } \\
\text { anytime, then there is a need to design } \\
\text { and implement KRIs that denote the } \\
\text { social nature of knowledge and its } \\
\text { current forms of production and } \\
\text { reproduction. This implies that these } \\
\text { instruments have the capacity to collect } \\
\text { and show the conditions under which } \\
\text { knowledge is produced in the modern } \\
\text { era. This will surely also mean that } \\
\text { future KRIs do not necessarily have the } \\
\text { form of 2D visualisation instruments but } \\
\text { in multiple dimensions. } \\
\text { Among several conditions, future KRIs } \\
\text { must, in turn, provide the necessary } \\
\text { conditions for knowledge to be } \\
\text { constructed and represented } \\
\text { collaboratively (Rodríguez, Hudson, \& } \\
\text { Niblock, 2018), distributed (Simpson \& } \\
\text { Du, 2004) and ubiquitous (Tahir, Haron, } \\
\text { \& Singh, 2018). }\end{array}$ \\
\hline $\begin{array}{l}\text { What are the } \\
\text { educational } \\
\text { activities and } \\
\text { processes in } \\
\text { which the } \\
\text { instruments of } \\
\text { knowledge } \\
\text { representation } \\
\text { are used? }\end{array}$ & $\begin{array}{l}\text { Four categories were identified that } \\
\text { allude to educational processes in } \\
\text { which KRIs are used: teaching, } \\
\text { organisation of information, } \\
\text { assessment and management. } \\
\text { Studies show that more than } 50 \% \text { of } \\
\text { these processes are related to } \\
\text { educational activities that point to the } \\
\text { development of LOTS in which KRIs } \\
\text { are used as linguistic resources that } \\
\text { teachers use to support learning } \\
\text { processes. The data indicate that about } \\
25 \% \text { of the investigations that report } \\
\text { the use of KRIs do so to evaluate }\end{array}$ & $\begin{array}{l}\text { Authors such as Levy (2007) and Cobo } \\
\text { (2016) point out that current knowledge } \\
\text { occurs in different ways and conditions } \\
\text { than those used in the past; These } \\
\text { authors point to the transforming role in } \\
\text { the digital society, of networking and of } \\
\text { the social construction of knowledge. } \\
\text { Therefore, we assume that the use of } \\
\text { KRIs will exceed the linguistic function } \\
\text { of current knowledge representation } \\
\text { tools and will gradually become } \\
\text { metalinguistic resources that demonstrate } \\
\text { the ways in which we produce } \\
\text { knowledge and how that knowledge is } \\
\text { created with specific cultural, }\end{array}$ \\
\hline
\end{tabular}




\begin{tabular}{|c|c|c|}
\hline & $\begin{array}{l}\text { student learning. These studies also } \\
\text { indicate that this evaluation is made } \\
\text { from the perspective of teachers, who } \\
\text { inquire about how students learn. } \\
\text { However, studies point to the difficulty } \\
\text { of establishing these same issues from } \\
\text { the students' perspectives, so questions } \\
\text { about how to learn to learn are still } \\
\text { valid. }\end{array}$ & $\begin{array}{l}\text { educational and social conditions. On the } \\
\text { other hand, if it is recognised that in } \\
\text { learning environments mediated by } \\
\text { digital technologies students with high } \\
\text { levels of autonomy, critical thinking and } \\
\text { self-regulation are required, then the } \\
\text { KRIs, can be suitable options to be used } \\
\text { as resources for the representation of } \\
\text { knowledge, but also as meta-evaluative } \\
\text { and metacognitive resources. } \\
\text { In this context, the digital fingerprints } \\
\text { produced by students in the digital } \\
\text { interaction spaces and not only the } \\
\text { formal representations of knowledge } \\
\text { made through conceptual cartography, } \\
\text { may eventually be part of a more } \\
\text { complex system of knowledge } \\
\text { representation instruments. } \\
\text { The abovementioned claims lead us to } \\
\text { suggest further studies that investigate } \\
\text { whether the current ontologies of } \\
\text { knowledge lead to knowledge ontologies } \\
\text { based on the semantic web (Munir \& } \\
\text { Sheraz-Anjum, 2018; Stephan, Pascal, \& } \\
\text { Andreas, 2007) }\end{array}$ \\
\hline $\begin{array}{l}\text { Which learning } \\
\text { theories guide } \\
\text { the use and } \\
\text { conception of } \\
\text { the instruments } \\
\text { of } \\
\text { representation } \\
\text { of knowledge in } \\
\text { those activities } \\
\text { and processes? }\end{array}$ & $\begin{array}{l}\text { Not all of the reviewed studies mention } \\
\text { a theory on which the use of KRIs in } \\
\text { education is based. Those that mention } \\
\text { it, point to behaviorism and } \\
\text { constructivism as base theories. }\end{array}$ & $\begin{array}{l}\text { Given the different understanding of the } \\
\text { concept of knowledge that the digital } \\
\text { society implies, the theories of learning } \\
\text { in which collaborative, distributed and } \\
\text { ubiquitous KRIs are used should emerge } \\
\text { and adapt to new theories of learning for } \\
\text { the digital age. Some of the principles on } \\
\text { which these adapted theories are based, } \\
\text { will surely find in the connectivism, a } \\
\text { more appropriate theory of learning } \\
\text { (Goldie, 2016). However, recognising } \\
\text { that the representation of knowledge will } \\
\text { be strongly mediated by digital } \\
\text { technologies and by the social nature of } \\
\text { knowledge, new theories that integrate } \\
\text { holistically these new realities of the } \\
\text { production and representation of } \\
\text { knowledge should emerge. These } \\
\text { theories should help to describe the roles } \\
\text { and functions of educational agents in } \\
\text { the learning process. }\end{array}$ \\
\hline $\begin{array}{l}\text { What thinking } \\
\text { skills are } \\
\text { promoted or } \\
\text { developed } \\
\text { through the } \\
\text { instruments of } \\
\text { knowledge } \\
\text { representation? }\end{array}$ & $\begin{array}{l}\text { Studies report the use of KRIs related } \\
\text { to all thinking skills, both at the level } \\
\text { of LOTS and HOTS. However, the } \\
\text { literature review allowed us to observe } \\
\text { that the use of KRIs is done most of the } \\
\text { time pointing to the development of } \\
\text { one of these levels, but not of the two } \\
\text { at the same time. This also applies to } \\
\text { activities related to thinking skills as } \\
\text { shown by studies such as those by } \\
\text { Driessen et al. (2007) and Kolkman et }\end{array}$ & $\begin{array}{l}\text { The representation of knowledge } \\
\text { continues to be a determining factor in } \\
\text { current teaching and learning processes, } \\
\text { however, the studies say little about the } \\
\text { use of KRIs in the formation of thinking } \\
\text { skills based on educational practices } \\
\text { based on the principles of the new digital } \\
\text { ecologies. } \\
\text { Studies have been conducted on the use } \\
\text { of KRIs in education such as those of } \\
\text { Novak (1990a, 1990b, 1998), O'Donnell }\end{array}$ \\
\hline
\end{tabular}




\begin{tabular}{|l|l|l|}
\hline & $\begin{array}{l}\text { al. (2005), which scarcely register the } \\
\text { simultaneous development of skills } \\
\text { related to different educational } \\
\text { processes. }\end{array}$ & $\begin{array}{l}\text { et al. (2002), Hay et al. (2008), Hegazy, } \\
\text { Ali, and Abdel-Monem (2011). } \\
\text { However, the phenomenon of KRIs must } \\
\text { be further studied in aspects such as } \\
\text { representation in processes of digital, } \\
\text { ubiquitous and collaborative construction } \\
\text { of knowledge and its impact on the } \\
\text { simultaneous development of thinking } \\
\text { skills in the digital age (Krathwohl, } \\
\text { 2002). }\end{array}$ \\
\hline
\end{tabular}

Although studies indicate that there is a percentage of the results related to the development of high level thinking skills (i.e., evaluate), a part of them is not linked to the development of such skills in students but in teachers as evaluating agents; that is, there is a sort of inversion of the use of KRIs. On the other hand, as van Laar, van Deursen, van Dijk, and de Haan (2017) mentions, the context of twenty-first century society requires the development of special skills in students, some of them referred to them as soft skills (Bell, 2010). In this sense, digital environments present an additional challenge for the development of such skills as collaboration, critical thinking, creativity, and communication, which must find an adequate response by a system of knowledge representation intentionally developed for the complex ecology of the digital learning environments.

Moreover, research on the representation of knowledge, despite being related to issues such as learning, do not detail or describe the learning theories on which their studies are based. This may be due to the fact that, they reinforced the idea that the representation of knowledge is strongly intricate with constructivist learning theories, giving such pedagogical support by default (Novak, 1988; Novak \& Cañas, 2006; 1984). Notwithstanding the above, it also indicates the lack of pedagogical theories and models on which to support the development of knowledge representation processes within an area that increasingly involves the use of computer programs and that rely on complex themes such as data mining, large-scale data management, and artificial intelligence. In this context, topics such as MOOCs, learning analytics and the extensive educational use of social networks represent a very interesting field of research to examine the usefulness of target knowledge representation systems and instruments.

The aforementioned considerations have effects both on policy-making and for educational practices. This is especially relevant for addressing the field of teaching, as the new digital environments do require new ways (with new protocols and rules of evaluation and monitoring) to identify the knowledge that is often hidden in the digital fingerprints of those who often participate in informal learning experiences, or of those who make use of alternative digital spaces to the ones used in traditional educational systems. In this regard, Seufert $(2003$, p. 1) notes that "the manipulation of two different formats of representation supports two different ways of penetrating the same learning content and can have synergistic effects on the construction of coherent structures of knowledge." This confirms Sowa's assumptions (2014) concerning the representation of knowledge occurring through different levels such as linguistic and metalinguistic. Perhaps, the formats referred by Seufert (2003) have to do with addressing KRIs through other interfaces, enriched by more than one individual (as it happens in social networks), thus provoking the possibility of understanding and constructing a concept from its metalinguistic dimension.

In this context, it is worth noting that the reviewed research provide added value in terms of the educational use of knowledge representation processes. However, considering the current state of research and the role they play today (Lévy, 2007), it becomes interesting to inquire about how processes such as writing, reading, generating and representing knowledge in a digital society are been modified as a product of the influx of technologies such as artificial intelligence. It is worth examining the new forms of interaction and communication that involve, for example, different ways of relating to information, different ways of generating and representing knowledge and different ways of understanding learning, perhaps towards a more collaborative, more open, more networked perspective (Cobo, 2016), and through intelligent instruments that record and save our experiences and people's learning trajectories (Cuesta \& Buitrago, 2017).

If so many years ago Ausubel (1963) spoke of the importance of experience and prior knowledge in the generation of new knowledge, why not then think that such knowledge, in today's digital environments 
would be available and visible permanently through KRIs so that they become techno-cognitive devices, able to periodically store our digital fingerprints and learning paths and with this, they allow to unveil the knowledge that we acquire or construct?

\section{References}

Adodo, S. O. (2013). Effect of mind-mapping as a self-regulated learning strategy on students' achievement in basic science and technology. Mediterranean Journal of Social Sciences, 4(6), 163172. https://doi.org/10.5901/mjss.2013.v4n6p163

Ausubel, D. P. (1963). The psychology of meaningful verbal learning. New York, NY: Grune \& Stratton. Retrieved from http://psycnet.apa.org/psycinfo/1964-10399-000

Balke, W. T., \& Mainzer, K. (2005). Knowledge representation and the embodied mind: Towards a philosophy and technology of personalized informatics. Proceedings of CEUR Workshop (Vol. 130, pp. 586-597). Kaiserslautern: Springer. Retrieved from https://goo.gl/6jrs6M

Bell, S. (2010). Project-based learning for the 21st Century: Skills for the future. The Clearing House: A Journal of Educational Strategies, Issues and Ideas, 83(2), 39-43. https://doi.org/10.1080/00098650903505415

Chang, K.-E., Sung, Y.-T., \& Chen, I.-D. (2002). The effect of concept mapping to enhance text comprehension and summarization. Journal of Experimental Education, 71(1), 5-23. Retrieved from https://goo.gl/DHkPJF

Churches, A. (2008). Bloom's digital taxonomy. TechLearning. Retrieved from http://www.pdst.ie/sites/default/files/BloomDigitalTaxonomy-AndrewChurches.pdf

Ciullo, S., Falcomata, T. S., Pfannenstiel, K., \& Billingsley, G. (2015). Improving learning with science and social studies text using computer-based concept maps for students with disabilities. Behavior Modification, 39(1), 117-135. https://doi.org/10.1177/0145445514552890

Cobo, C. (2016). La Innovación Pendiente.: Reflexiones (y Provocaciones) sobre educación, tecnología y conocimiento. Montevideo: Penguin Random House. Retrieved from https://goo.gl/xybbZ1

Correia, P. R. M. (2012). The use of concept maps for knowledge management: From classrooms to research labs. Analytical and Bioanalytical Chemistry, 402(6), 1979-1986. https://doi.org/10.1007/s00216-011-5694-8

Cuesta, L., \& Buitrago, M. (2017). Discovering students' digital footprints in their learning trajectories. In J. Colpaert, A. Aerts, R. Kern, \& M. Kaiser (Eds.), Proceedings of CALL in CONTEXT (pp. 17-25). Berkeley, CA: University of Berkeley. Retrieved from http://call2017.language.berkeley.edu/wpcontent/uploads/2017/07/CALL2017 proceedings.pdf

Davies, M. (2011). Concept mapping, mind mapping and argument mapping: What are the differences and do they matter? Higher Education, 62(3), 279-301. https://doi.org/10.1007/s10734-010-9387-6

Defranco, J. F., Jablokow, K. W., Bilen, S. G., \& Gordon, A. (2012). The impact of cognitive style on concept mapping: Visualizing variations in the structure of ideas. Proceedings of ASEE Annual Conference and Exposition (1-17), San Antonio, TX.

Defranco, J. F., Jablokow, K. W., Piovoso, M. J., \& Richmond, S. S. (2015). Objectively assessing concept maps for knowledge integration. International Journal of Engineering Education, 31(5), 1288-1298. Retrieved from https://goo.gl/bFZnru

Dexter, D. D., \& Hughes, C. A. (2011). Graphic organizers and students with learning disabilities: A meta-analysis. Learning Disability Quarterly, 34(1), 51-72. https://doi.org/10.1177/073194871103400104

Driessen, S., Huijsen, W., \& Grootveld, M. (2007). A framework for evaluating knowledge-mapping tools. Journal of Knowledge Management, 11(2), 109-117. https://doi.org/10.1108/13673270710738960

Drucker, P.F., (2011). Post-capitalist society, New York, NY: Routledge.

Fedorenko, E., Nieto-Castañon, A., \& Kanwisher, N. (2012). Lexical and syntactic representations in the brain: An fMRI investigation with multi-voxel pattern analyses. Neuropsychologia, 50(4), 499-513. https://doi.org/10.1016/j.neuropsychologia.2011.09.014

Fionda, V., Gutierrez, C., \& Pirrò, G. (2016). Building knowledge maps of Web graphs. Artificial Intelligence, 239, 143-167. https://doi.org/10.1016/j.artint.2016.07.003

Gog, T. ., Kester, L., Nievelstein, F., Giesbers, B., \& Paas, F. (2009). Uncovering cognitive processes: Different techniques that can contribute to cognitive load research and instruction. Computers in Human Behavior, 25(2), 325-331. https://doi.org/10.1016/j.chb.2008.12.021

Goldberg, R. F., Perfetti, C. A., \& Schneider, W. (2006). Perceptual knowledge retrieval activates sensory 
brain regions. Journal of Neuroscience, 26(18), 4917-4921.

https://doi.org/10.1523/JNEUROSCI.5389-05.2006

Goldie, J. G. S. (2016). Connectivism: A knowledge learning theory for the digital age? Medical Teacher, 38(10), 1064-1069. https://doi.org/10.3109/0142159X.2016.1173661

Gordon, J. (2000). Creating knowledge maps by exploiting dependent relationships. Knowledge-Based Systems, 13(2), 71-79. https://doi.org/10.1016/S0950-7051(00)00048-4

Guimarães, N., Chambel, T., \& Bidarra, J. (2000). From cognitive maps to hypervideo: Supporting flexible and rich learner-centred environments. Interactive Multimedia Electronic Journal of Computer - Enhanced Learning, 2(2), 1-7. Retrieved from https://goo.gl/W7FvVg

Hall, T., Beecham, S., Bowes, D., Gray, D., \& Counsell, S. (2012). A systematic literature review on fault prediction performance in software engineering. IEEE Transactions on Software Engineering, 38(6), 1276-1304. https://doi.org/10.1109/TSE.2011.103

Hay, D., Kinchin, I., \& Lygo-Baker, S. (2008). Making learning visible: The role of concept mapping in higher education. Studies in Higher Education, 33(3), 295-311. https://doi.org/10.1080/03075070802049251

Hegazy, T., Ali, A., \& Abdel-Monem, M. (2011). Prospects of mind maps for better visualization of infrastructure literature. Journal of Professional Issues in Engineering Education \& Practice, 137(4), 239-247. https://doi.org/10.1061/(ASCE)EI.1943-5541.0000072

Jablokow, K. W., Defranco, J. F., Richmond, S. S., Piovoso, M. J., \& Bilén, S. G. (2015). Cognitive style and concept mapping performance. Journal of Engineering Education, 104(3), 303-325. https://doi.org/10.1002/jee.20076

Jacobs-Lawson, J. M., \& Hershey, D. A. (2002). Concept maps as an assessment tool in psychology Courses. Teaching of Psychology, 29(1), 25-29. https://doi.org/10.1207/S15328023TOP2901 06

Jahan, M., \& Hamilton, H. J. (2017). A knowledge acquisition system for price change rules. Lecture Notes in Computer Science (Including Subseries Lecture Notes in Artificial Intelligence and Lecture Notes in Bioinformatics), 10233, 215-226. https://doi.org/10.1007/978-3-319-57351-9 26

Juuti, T. S., Lehtonen, T. A., \& Rättyä, K. (2012). Product development education-conceptual modelling, knowledge integration and metacognition. Proceedings of the 14th International Conference on Engineering and Product Design Education: Design Education for Future Wellbeing, EPDE 2012 (pp. 1-6). Antwerp: Artesis University College. Retrieved from http://www.designsociety.org/publication/33171/product_development_educationconceptual_modelling_knowledge integration_and metacognition

Ke, F. (2009). A qualitative meta-analysis of computer games as learning tools. In R. E. Ferdig (Ed.), Handbook of research on effective electronic gaming in education (pp. 1-32). Hershey, PA: IGI Global. https://doi.org/10.4018/978-1-59904-808-6

Kolkman, M. J., Kok, M., \& van der Veen, A. (2005). Mental model mapping as a new tool to analyse the use of information in decision-making in integrated water management. Physics and Chemistry of the Earth, 30(4-5 SPEC. ISS.), 317-332. https://doi.org/10.1016/j.pce.2005.01.002

Krathwohl, D. R. (2002). A revision of Bloom's taxonomy: An overview. Theory Into Practice, 41(4), 212-218. https://doi.org/10.1207/s15430421tip4104_2

Lévy, P. (2007). Cibercultura: informe al Consejo de Europa (Vol. 16). Barcelona: Anthropos Editorial. Retrieved from https://goo.gl/S2CNtg

Munir, K., \& Sheraz-Anjum, M. (2018). The use of ontologies for effective knowledge modelling and information retrieval. Applied Computing and Informatics, 14(2), 116-126. https://doi.org/10.1016/j.aci.2017.07.003

McLay, M., \& Brown, M. (2003). Using concept mapping to evaluate the training of primary school leaders. International Journal of Leadership in Education: Theory and Practice, 6(1), 73-87.

Novak, J. D. (1988). Constructivismo humano: un consenso emergente. Enseñanza de Las Ciencias: Revista de Investigación y Experiencias Didácticas, 6(3), 213-223. Retrieved from http://www.raco.cat/index.php/ensenanza/article/viewFile/51070/92966

Novak, J. D. (1990a). Concept mapping: A useful tool for science education. Journal of Research in Science Teaching, 27(10), 937-949. https://doi.org/10.1002/tea.3660271003

Novak, J. D. (1990b). Concept maps and Vee diagrams: Two metacognitive tools to facilitate meaningful learning. Instructional Science, 19(1), 29-52. https://doi.org/10.1007/BF00377984

Novak, J. D., \& Cañas, A. J. (2006). The origins of the concept mapping tool and the continuing evolution of the tool. Information Visualization, 5(3), 175-184. https://doi.org/10.1057/palgrave.ivs.9500126

Novak, J. D., Gowin, D., \& Johansen, G. T. (1983). The use of concept mapping and knowledge vee 
mapping with junior high school science students. Science Education, 67(5), 625-645.

https://doi.org/10.1002/sce.3730670511

O’Donnell, A. M., Dansereau, D. F., \& Hall, R. H. (2002). Knowledge maps as scaffolds for cognitive processing. Educational Psychology Review, 14(1), 71-86. https://doi.org/10.1023/A:1013132527007

Richland, L. E., \& Hansen, J. (2013). Reducing cognitive load in learning by analogy. International Journal of Psychological Studies, 5(4), 69. Retrieved from http://www.ccsenet.org/journal/index.php/ijps/article/view/25611 http://dx.doi.org/10.5539/ijps.v5n4p69

Rodríguez, A. (2012). A recommender system supporting teachers to author learning sessions in decisionmaking. Intelligent Techniques in Recommendation Systems: Contextual Advancements and New Methods. Retrieved from https://goo.gl/JGYCex

Rodriguez, C., Hudson, R., \& Niblock, C. (2018). Collaborative learning in architectural education: Benefits of combining conventional studio, virtual design studio and live projects. British Journal of Educational Technology, 49(3), 337-353. https://doi.org/10.1111/bjet.12535

Ruddell, R., \& Boyle, O. (1989). A study of the effects of cognitive mapping on reading comprehension and written protocols. Reading Research and Instructions, 29(1), 12-22.

Seufert, T. (2003). Supporting coherence formation in learning from multiple representations. Learning and Instruction, 13(2), 227-237. https://doi.org/10.1016/S0959-4752(02)00022-1

Simpson, C., \& Du, Y. (2004). Effects of learning styles and class participation on students' enjoyment level in distributed learning environments. Journal of Education for Library and Information Science, 45(2), 123-136. https://doi.org/10.2307/40323899

Skiba, D. J. (2013). Bloom's digital taxonomy and word clouds. Nursing Education Perspectives, 34(4), 277-280. Retrieved from http://journals.lww.com/neponline/Citation/2013/07000/Bloom_s_Digital_Taxonomy_and_Word_Clo uds.15.aspx

Sowa, J. F. (2014). Principles of semantic networks: Explorations in the representation of knowledge. San Mateo, CA: Morgan Kaufmann. Retrieved from https://goo.gl/zHDdjM

Stephan, G., Pascal, H., \& Andreas, A. (2007). Knowledge representation and ontologies. In R. Studer, S. Grimm, \& A. Abecker (Eds.), Semantic web services (pp. 51-105). Berlin: Springer. https://doi.org/10.1007/3-540-70894-4_3

Tahir, Z. M., Haron, H., \& Singh, J. K. G. (2018). Evolution of learning environment: A review of ubiquitous learning paradigm characteristics. Indonesian Journal of Electrical Engineering and Computer Science, 11(1), 175-181.

Tseng, K.-H., Chang, C.-C., Lou, S.-J., Tan, Y., \& Chiu, C.-J. (2012). How concept-mapping perception navigates student knowledge transfer: Performance. Educational Technology and Society, 15(1), 102115. Retrieved from https://goo.gl/2vPBjS

Valenzuela, J. (2008). Habilidades de pensamiento y aprendizaje profundo. Revista Iberoamericana de Educación, 46(7), 1-9. Retrieved from https://rieoei.org/RIE/article/view/1914

van Laar, E., van Deursen, A. J. A. M., van Dijk, J. A. G. M., \& de Haan, J. (2017). The relation between 21st-century skills and digital skills: A systematic literature review. Computers in Human Behavior, 72(July), 577-588. https://doi.org/10.1016/j.chb.2017.03.010

Vieira, S., Kaymak, U., \& Sousa, J. (2010, July). Cohen's Kappa coefficient as a performance measure for feature selection. Paper presented at the 2010 IEEE International Conference on Fuzzy Systems (pp. 1-8). Barcelona, Spain: IEEE. https://doi.org/10.1109/FUZZY.2010.5584447

Whimbey, A., Lochhead, J., \& Narode, R. (2013). Problem solving \& comprehension (7th ed.). New York, NY: Routledge. Retrieved from https://goo.gl/hoHvDN

Corresponding author: Andrés Chiappe, andres.chiappe@unisabana.edu.co

Australasian Journal of Educational Technology (C) 2019.

Please cite as: Buitrago, M., \& Chiappe, A. (2019). Representation of knowledge in digital educational environments: A systematic review of literature. Australasian Journal of Educational Technology, 35(4), 46-62. https://doi.org/10.14742/ajet.4041 